\title{
Planning For Instructional Resources For Science Based Subjects In Secondary Schools In Kenya: Addressing Financing Options
}

\author{
Paul Amolloh Odundo \\ University of Nairobi \\ School of Education \\ Charles Richard Oyier \\ University of Nairobi \\ School of Education
}

\begin{abstract}
Instructional resources are educational inputs necessary for raising quality of education across the school system. Planning for instructional resources include setting aside money through budgetary allocation for procurement of resources. An assurance for availability and adequacy of instructional resources require defined sources of funds and standardized procedures with appropriate financial base for prudent utilization. Interaction between policy and practice in budgeting process assures efficient utilization of finance for science instructional resources in schools. The study focussed on identification of gaps within national educational policy framework on budgeting process which influence planning for science instructional resources. Specifically, determining extent to which policy framework supports budgetary allocation, financial resources, standardized procedures and financial accountability in science instructional management. The study adopted frontloading approach, a methodological process that translates (inter)national human rights standards and obligations into the budget proposals required for effective implementation in public policy. The study reviewed legal instruments, publications, reports and documentation on instructional management. Findings indicated that, domesticating ICESCR in Constitution of Kenya (2010) scanty policy guidelines on issues of quality instruction; limited specific provision for budgetary allocation for science instructional resources, as much as FDSE provide no budgetary guidelines on bridging deficits, adherence to legal provision guiding procurement procedures and accountability. The study recommends streamlining of policies to entrench framework support for implementation and monitoring and evaluation of resource allocation for quality of instruction and management.
\end{abstract}

KEY WORDS: Budgeting Process, Utilization of Instructional Resources, Policy Framework, Human Rights

\section{INTRODUCTION}

Science is an instrument for development that plays dominant role in spearheading technological advancement, promoting national wealth and accelerating industrialization. According to Mascitti-Miller (2012) science education is a pillar in technological development and stimulates economic growth. Provision for quality science and mathematics instruction is valuable in spurring national development. Amunga, Amadalo and Musera (2011) asserted that sciences and mathematics equip learners with manipulative skills necessary for technological development and economic growth. Achieving national economic growth therefore require appropriate utilization of science instructional methods and resources provided through budgetary process at secondary school level. Supporting this position Gichohi (2015) noted that quality science instructions can only be achieved when resources are made available through adequate budgetary allocation. In Kenya, the national educational policy framework guides provision of quality instructional management through a number of legislations and 
policy papers. These legislations and policy papers provisions are derived from international legal instruments that regard education as human right (Kumbi 2015). As an integral part of economic, social and cultural rights (ESCRs), education is perceived as legitimate in terms of both individual and collective good, resulting into growth both in national and global arena (Kung, Huang \& Cheng (2015).

\section{National Educational Policy Framework (2005) and Quality Science Instructions}

Science education is a pillar in development in any nation. Quality science instruction is not only a prerequisite in fulfilment of education as human right but basic requirement in technological and economic advancement in any country (Mbugua \& Rarieya, 2014). Provision of quality instructions and especially for science education is more valuable as far as national development is concerned. Realization of quality instruction is dependent on educational policy framework particularly on national budgetary allocation for improved learning achievement in science based subjects (Nolan, 2013). Kenya national educational policy framework(2005) should influence science instruction through budgetary allocation to secondary schools. Agreeing with the position, Mascitti-Miller (2012) underscored that policy driven budgeting process in promoting quality science instructions is essential for achieving industrialized status. National Education policy framework would therefore influence adequacy, availability and utilization of instructional resources through a budgeting process in secondary schools. In Kenya, the government through FSE policy provides finances for the purchase of instructional resources in public secondary schools based on enrolment. However, funding to ensure adequate instructional resources for science subject could only be achieved from the basis of legal instruments within educational policy framework informing budgeting process in secondary schools. This study looked at the gaps in national educational policy framework on school budget management strategy and influence of budgetary allocation for science instructional resources in secondary schools in Kenya.

\section{School Budget Management Policy and Quality Science Instructions}

Quality science instructions in secondary schools require an institutional budget management policy to influence budgetary allocation teaching and learning resources for chemistry, biology and physics. Supporting this position Wagithunu, Muthee and Thinguri (2014) noted that school budgeting policy provides a system for budgetary allocations, budget control and accountability measures to ensure appropriate utilization of science instructional resources. Further, Gichohi (2015) noted that school budget management policy enables educational institutions to organize and manage funds for effective science instructions. In practice school budget management policy should provide a leadership framework for ensuring availability and adequacy of instructional resources which would enable learners understand science concepts. Echoing these sentiments, Kung et al (2015) asserted that school budget management policy should be designed with regard to enrollment, infrastructure and staffing purposely for realization of institutional science instructional goal. To achieve science instructional goals in secondary schools through adequate budgetary allocations gaps in national educational policy framework needs to be identified and addressed. This study sought to identify Kenya educational policy framework with focus on how it influence science instructional management through budgetary allocation at secondary schools level.

\section{Statement of the Problem}

Educational policy framework from national level should influence science instructional management in secondary schools in any country. Quality science instruction is dependent on adequate budgetary allocation for teaching and learning resources for biology, chemistry and physics in secondary schools. Budgetary allocations and utilization of science instructional resources at secondary schools are determined by tenets of national educational policy 
framework which are hinged on international instruments on education as a human right. This made it necessary to trace gaps on Kenya national educational policy framework with focus on how it would influence budgetary allocation and utilization of science instructional resources in secondary schools. From national platform to secondary schools financial policy framework provisions for quality science instructions through budgeting process need to ensure adequacy, availability and utilization of instructional resources. In this study focus on identifying gaps on Kenya national educational policy framework influencing budgetary allocation and utilization of science instructional resources in secondary schools.

\section{THEORETICAL FRAMEWORK}

This study adopted a methodological process used to offer budget recommendations on the basis of (inter)national human rights standards known as frontloading. Nolan (2013) defined frontloading as a methodological process that translates (inter)national human rights standards and obligations into the budget proposals required for effective implementation in public policy and budget cycles. Allocation of funds for tuition as part of FSE policy has implications for the fulfillment of quality education as human rights depending on how sufficient the level of financing would be to raise level of adequate instructional resource for learning at school. As noted by Chetambve and Sakwa (2013) allocation for tuition through FSE policy is inadequate in ensuring availability for instructional resource. This position is supported by UNESCO (2015) assertion that often governments adopted laws and policies that are not implemented due to insufficient funding. Frontloading allows application all rightsbased budgeting analysis frameworks on macro-level quantities to micro-level qualities focusing on circumstances of particular right, in case realization of quality instructions from funds allocated to tuition through FSE policy. To adequately allocate resources for instructional management, level of resources a government allocates to tuition in secondary schools determines quality of Education. 


\section{CONCEPTUAL FRAMEWORK}

Figure 1: Policy Framework for Realization of Quality Instruction as an Educational Right

\begin{tabular}{|c|c|c|c|}
\hline Declaration & Domestication & Realization & Fulfillment \\
\hline$\sqrt{3}$ & $\sqrt{3}$ & $\sqrt{3}$ & 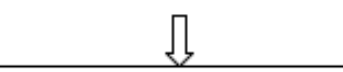 \\
\hline $\begin{array}{l}\text { International Policy } \\
\text { Instruments } \\
\text {-Universal Declaration of } \\
\text { Human Rights (UDHR) }\end{array}$ & $\begin{array}{l}\text { National Legal } \\
\text { Instruments } \\
\text {-Constitution of Kenya } \\
\text { Of } 2010\end{array}$ & $\begin{array}{l}\text { Educational } \\
\text { Policies } \\
\text {-A policy Framework for } \\
\text { Education and Training }\end{array}$ & $\begin{array}{l}\text { School Financial } \\
\text { Management Policy }\end{array}$ \\
\hline $\begin{array}{l}\text { (1948), } \\
\text {-International Covenant on } \\
\text { Economic, Social and Cultural } \\
\text { Rights (ICESCRs) (1966) } \\
\text {-World Declaration on } \\
\text { Education (WDE) in (1990) } \\
\text {-African Charter on the Rights } \\
\text { and Welfare of the Child }\end{array}$ & $\begin{array}{l}\text {-Basic Education Act Of } \\
2012 \\
\text {-Children's Act } 2001 \\
\text {-Public Finance } \\
\text { Management Act of } \\
2012 \\
\text {-Public Procurement and } \\
\text { Disposal Act 2005 }\end{array}$ & $\begin{array}{l}\text { of } 2012 \\
\text {-Free Day Secondary } \\
\text { Education Policy of } 2008 \\
\text {-Kenya Education Sector } \\
\text { Support Programme } \\
\text { (KESSP) } \\
\text {-Public procurement } \\
\text { Manual for Schools \& }\end{array}$ & $\begin{array}{l}\text {-Budgetary allocation, } \\
\text {-Sources of different } \\
\text { financial resources, } \\
\text {-Standardized procedures } \\
\text {-Financial accountability }\end{array}$ \\
\hline $\begin{array}{l}\text {-United Nations Convention } \\
\text { on the Rights of the Child } \\
\text { (CRC) (1989) } \\
\text {-Sustainable Development }\end{array}$ & & $\sqrt{5}$ & \\
\hline Goals (SDGs) (2016) & Quality & ce Instruction in & dary Schools \\
\hline
\end{tabular}

\section{METHODOLOGY}

This study merged theory with practice by relying on related literature review of statutes, policy papers, treaties and reports on education as a human rights issue. A desk review was conducted to establish the most recent developments and trends in the education sector policy, which involved a comprehensive study of legal instruments, publications, reports and documentation on instructional management. The study was contemporary and assessed ongoing reforms in the education sector in Kenya with a view to informing theory and practice on budgeting process for planning and utilization of science instructional resources in secondary schools

\section{FINDINGS AND DISCUSSION}

National educational policy framework (2005) is combination of legal instruments developed for the purpose of domestication, realization and fulfilment of education as human right. In realization and fulfilling right to education, national educational policy framework needs to appreciate role science subjects in technological advancement, national wealth creation and spearheading industrialization. This study was focussed on identification of gaps in policy framework on issues of quality science instruction; budgetary allocation for science instructional resources, procurement procedures for science instructional resources and accountability in science instructional management in secondary schools.

\section{International Covenant on Economic, Social and Cultural Rights (ICESCRs) of 1966}

The Universal Declaration of Human Rights (UDHR) of 1948 in Article 2, International Covenant on Economic, Social and Cultural Rights (ICESCRs) of 1966 in Article 13 stated that everyone has the right to education (Nolan 2013). Education as a human right was reaffirmed at the World Declaration on Education for all (WDE) Jomtien, Thailand in 1990 ( Wadesango,. 2012). As a way of fulfillment of UDHR (1948), ICESCRs (1966) and WDE (1990), in 2000 an international conference on education held in Dakar, Senegal came up with the initiative called Education for All (EFA), to encourage countries to work towards making education accessible to all by 2015 (Hussein, 2015) with no emphasis on quality instructions. UDHR (1948) highlights the right to education; including those relating to specific groups such as children, 
racial minorities, and women, but ICESCR provides the most comprehensive provisions. For instance Article 13(1) of ICESCR state in part that education shall be directed to the full development of persons to strengthen the respect for human rights; Article 13(2b) emphasizes that secondary education shall be made generally available and accessible to all by appropriate means and in particular progressively made free. In addition to article 13 which is the main provision, while other articles targeting education include Article 6(2) which obligates states party to create and implement training programs to fully realize the right to work and Article $10(1)$ that calls for protection and assistance of families in their responsibility in educating children. Reaffirmation of right to education as noted by Wadesango (2012), was made through WDE in Jomtien in 1990 by stressing tapping each individual's talents and potential while developing learners' personalities, to improve lives and transform societies. The Jomtien 1990 conference was concerned with quantity without stressing quality through making instructional resource not only available but also adequate in schools (Hussein, 2015). Highlighting the need for quality instruction through budgetary provision for teaching and learning resources for science based subject would lead into technological advancement, national wealth creation and spearheading industrialization.

\section{Free Day Secondary Education Policy (2007)}

In 1972 Kenya signed ICESCR as a declaration of education as a human right which would require better focus on sciences as means towards industrialization and wealth creation. In 2003, Kenya launched FPE, while FDSE was initiated in 2007 as results for political campaigns after elections. This meant launching before policy papers were developed to address issues of quality instruction in sciences and were purely intended for realization of World Declaration on Education of 1990 ( Chaudhury et al 2006). Later, a budgeting framework for guiding planning for educational goals was provided for in FDSE policy. According to FDSE policy, the government meets fees of Kshs. 10,265 per student in secondary school broken down as shown in Table 2

Table 1: Breakdown of Allocation of FSE in Vote Heads per Student

\begin{tabular}{llc}
\hline S/No. & Vote Head & Amount (Ksh) \\
1 & Tuition & 3,600 \\
2 & Repairs, Maintenance and Improvement & 400 \\
3 & Local Travel and Transport & 400 \\
4 & Administrative Costs & 500 \\
5 & Electricity, Water and Conservancy & 500 \\
6 & Activity & 600 \\
7 & Personal Emolument & 3,965 \\
8 & Medical & 300 \\
Total & & $\mathbf{1 0 , 2 6 5}$ \\
\hline
\end{tabular}

\section{Source: MOEST, Nairobi (2016)}

Table 1 indicates that tuition is allocated Kshs: 3600, which is expected to finance instructional resources. While the provision of FDSE was commendable, there is no empirical evidence on how science instructional management was to be developed. At secondary school level, adequacy and availability of science instructional resources is determined by a financial management framework guiding the budgeting process. Therefore secondary schools are expected to have financial management framework to guide budgeting process by looking at how effectively science instructional resources could be availed for better learning outcomes. Learners' achievement in science subjects should be a product of effective utilization of instructional resources provided for in FDSE policy as budgetary provision for tuition (Oyier, 
Odundo, Ngauriaya \& Mwangi, 2017). However, there is no policy directive on compelling secondary schools to allocate a given portion on science instructional resources. This is in tandem with findings from study on effective management of schools in Ghana by Drah (2011) who noted government's failure to put in place a policy framework on minimum standards in relation to provision of science instructional resources. Wagithunu, Muthee and Thinguri (2014), looked at extent to which FDSE policy has contributed to availability of instructional resources in secondary schools and suggested the need of a clear guideline on spending KES: 3600 meant for tuition per learner. The contribution of FDSE on availability of science instructional requires school level financial management to guide budgetary allocation for effective learning outcome. A school budgeting policy would therefore guide planning, monitoring and controlling the utilization of instructional resources towards desirable learning achievements in science subjects.

\section{Sessional Paper No. 1 of 2005 on Education, Training and Research}

Sessional Paper No. 1 of 2005 on education, training and research was developed and adopted to bring reforms through a Sector Wide Approach to Planning (SWAP) for the purpose of improving quality of instructions in science secondary schools. The sessional paper emphasized access, equity, quality, relevance and the strengthening of governance with no provision on how to make instructional resources adequate and available, (Kaguri, Njati \& Thiaine, 2014). For effective learning in sciences Gichohi (2015) as well as Nolan (2013) suggested that schools need a framework for budgeting to oversee, direct, conduct, regulate and control instructional management. Such a framework as noted by Kipkoech and Chesire (2011) should be intended to provide leadership with basis for ensuring adequate allocation utilization of instructional resources to help students understand the concepts in science subjects. Further, through Sessional Paper No. 1 (2005), Kenya Government had anticipated that in the long run, secondary education would be integrated as part of basic education. This has already been achieved through Basic Education Act of 2015; however there is no provision guiding budgetary allocation and utilization of science instructional resources in secondary schools. As suggested by Oyier and Odundo (2017) money needs to be set aside through budgeting process for science instructional resources and requires policy guidance. As much as Sessional Paper No. 1 of 2005 was intended to reform education through instructional management planning for quality instruction demands that money be set aside teaching and learning resources in secondary schools.

\section{Constitution of Kenya (2010) and Quality Science Instruction}

Domestication of ICESCR came in Constitution of Kenya (2010), by recognizing education as human right Article 43. Secondly, articles 43.1f, 53.1b and 55a makes education a right of every citizen and like FPE and FDSE which came into force earlier, issues of quality science instructions was not addressed. Further, in Schedule 4 it is stipulated that among the roles of national government are education policy and standards. Instructional management in secondary schools falls within these functions and is expected to be addressed through parliamentary legislations and ministerial policy papers. Given that Vision 2030 underscores the importance of science subjects in ensuring relevant human and social capital for sustainable development, Constitution of Kenya (2010) provides a basis for adequate budgetary allocation for instructional resources through legislation. This is further highlighted in article 11(2) (b) and (c) which recognises the role of science in the development of the nation on top of guaranteeing every child to free and compulsory basic education. However, to achieve transformational knowledge based economy as suggested in Vision 2030 adequate budgetary allocation and utilization of science instructional resources requires a legislative policy framework (Oyier et al, 2017) 
On financial management to ensure adequate budgetary allocation for science instructional resources is realized and managed for effective learning, article 10(2) of the Constitution sets out the national values and principles of governance. These include inter alia inclusiveness, good governance, integrity, transparency and accountability. Together with provisions of chapter 13, the constitution lays a basis for secondary schools boards of managements (BOMs) with values and principles key in managing schools resources for effective science instructional management. Such values according to Odundo and Oyier (2017), define school financial management leadership which directly influence budgetary allocations for science instructional resources. Further in Articles 20, 35, 42, 43 and 53 have an emphasis on education as a human right and Nolan (2013) asserted that countries to be guided by the principle that it is own responsibility to have resources to implement educational programmes. The constitution may not be explicit on resources for science instructional management in secondary, but accompanying legislation need to provide direction on sources of funds.

Values and principles in Article 232 of the constitution according to Odundo and Oyier (2017), define how secondary school financial management leadership would efficiently and effectively manage available resources. Prudent financial leadership in secondary schools provides the most economical way to ensures quality science instructions through adequate budgetary allocation and utilization. Specifically, Article 232 (1a), talks of high standards of professional ethics which would require secondary schools leadership to work with science teachers in determination and management of budgetary allocations for science instructional resources. Operationalizing Article 232 (1a) through parliamentary legislation would improve utilization of instructional resources through sourcing or procurement in most accountable way possible. This is further emphasized in Articles 201(a), (d), and (e); 226 and 227 on public finance relating to transparency, accountability, and appropriate governance of public monies. As noted by Joubert and Bray (2007) in an article on public schools administration it is prudent to be accountable for effective instructional management. Specific guideline on science teachers' involvement in budgetary allocations and management of resources for effective learning in sciences could be traced from Article 237 on the Teachers Service Commission Act 2012.

Effective science instructional management requires secondary school principals to solicit support for respective subject teachers in school budgeting process to ensure adequate budgetary allocation for teaching and learning resources. This requires further legislations to operationalize Chapter 13 of the constitution to address involvement of science teachers in budgeting for instruction resources. As noted by Anderson (2008) budgeting for instructional resources is part of school financial management provides the most visible ways through which science teachers can participate in decision making in secondary schools, hence the need for policy guideline. This will ensure adequate budgetary allocation for science instructional resources to make resources available for effective utilization as a determinant of good learning outcome and overall performance of the school

\section{Kenya Vision 2030}

The Kenya Vision 2030 is the national long-term development policy aiming at transformation into a new industrialized and middle-income country by 2030. The Vision recognises the role of science, technology and innovation (ST\&I) in a modern economy, which can only be realized through effective learning at all levels of education. Science instruction is expected to be the principle catalyst towards realization of Vision 2030. Quality science instructional management results into an educated and skilled population that would create, share and use knowledge towards industrialization in Kenya. As much as Vision 2030 recognizes that in the process of the emergence of the knowledge economy is associated with an increase in science- 
related and technology-based activities, it does not specifically underscore instructional management. To adequately improve on the national pool of scientific skills and talent adequate budgetary planning, allocation, monitoring and control for science instructional resources is essential. So long as policy framework on education address budgetary implications for science instructional management Vision 2030 envisaged curriculum that would lead to national pool of scientific knowledge, skills and competencies to meet the human capital needs of the country. The goal is to develop a repertoire of skills and competencies necessary to achieve the objectives and goals embodied in the Constitution, 2010 and Kenya Vision 2030. Under the policy and the subsequent legislative framework, the Government should provide free and compulsory basic education that is qualitative and relevant to Kenya's development goals through quality instructional management. Particularly, this would be vital in clarifying on budgetary allocation for science instructional resources to enhance utilization with focus on national development agenda through quality education across the school system.

\section{Sessional Paper No14 of 2012}

Article 11(2) (b) and (c) of the Constitution of Kenya (2010) recognises the role of science in the development of the nation on top of guaranteeing every child free and compulsory basic education. This is guided by the principle of universal access to education for every child under 18, as enshrined in Article 53 of the Constitution. Every child is entitled to free and quality education, regardless of social condition, gender, regional background, and disabilities. This is operationalized in Sessional Paper No14 of 2012 as a policy framework for education and training. Sessional Paper No14 of 2012 contains educational reforms anchored in Bill of Rights of the Constitution of Kenya (2010) which has no specific provision for quality instructions in science subjects. Learners' achievement in science subjects are products of effective utilization of instructional resources provided for in FDSE policy as budgetary provision for tuition. Therefore realization of Sessional Paper No14 of 2012 aspirations could partly be achieved through school level financial management policy which would ensure adequate budgetary allocation for science instructional resources. This would further enhance utilization of science instructional resources for knowledge acquisition and skills necessary for national development and economic take off toward middle level income country.

\section{Basic Education Act of 2015}

The constitution may not be explicit on resources for science instructional management in secondary, but accompanying legislation need to provide direction on sources of funds. As a requirements of the constitution, Basic Education Act of 2015 repealed Education Act 211 of 1968 (revised 1980) to modernise Kenyan educational management. In Article 86 (2), the Act highlights the need for adequate funding of secondary education without elaborating on budgetary allocation for science instructional resources. This failed to address quality science instruction which is lacking in Science and Technology Act of 2009. Secondly, as much as emphasis is on training shifts from knowledge-reproduction to knowledge-production it does not provide a clear policy guideline towards quality science instructions. Thirdly, it highlights on reforming management of education and make it functionally relevant to the provisions of the constitution without emphasis budgeting process towards realization of better learning outcome. However, it has emphasis on efficiency in delivery of education through creation of structures to ensure public participation in the management. This is key science instructional management and according to Odundo and Oyier (2017) recognition the role of science teachers in budgeting process go a long way in effective utilization of teaching and learning resources. Further, it echoes Mbugua and Rarieya (2014) assertion that participation of science teachers in budgeting process would be vital in overseeing, directing, conducting, regulating and controlling in science instructional management. Further, a policy on science teacher 
involvement in budgeting for instructional resources would enhance knowledge acquisition and gaining of skill for national economic development.

\section{Children Act of 2011}

Education in the Children Act of 2011 means the giving of intellectual, moral, spiritual instruction or other training to a child. Children Acts of 2011 operationalized Articles 53 of the Constitution provisions on children's right to free, compulsory and quality basic education, . This provision however, has no direct influence on science education and budgetary allocation for relevant instructional resources. Right to education as provided for in Article 7 which emphasizes responsibility government and parents in funding education, but without clarity for budgeting for instructional resources. This is in agreement with Chetambve and Sakwa (2013) assertion that as much as instructional management in public secondary schools is mainly financed by the government there is need for a policy guidance on budgetary allocations for science teaching and learning resources. According Kaguri, Njati and Thiaine (2014), the government through FDSE policy meets fees of Kshs. 10,265 per student in secondary school out of which Kshs: 3600 is for tuition and should cater for science instructional resources. Schools can also finance budgetary allocations for instructional resources from fees paid by parents, funds from income generating projects, contributions or donations by private sources and special grants from government (Kumbi, 2015). In ensuring adequate budgetary allocation for science instructional resources, schools will be fulfilling provisions of Article 7(2) Children Act 2011 and Article 28 of the United Nations Convention on the Rights of the Child. However, there is a need to emphasize through a policy or legislative process the need for adequate budgetary allocations for science instructional resources to enhance utilization for children individual development.

\section{Teachers Service Commission (TSC) Act 2012}

Article 237 of the constitution accords special status to the Teachers Service Commission (TSC), whose main role is teacher management. The TSC Act of 2012 converted the TSC, previously a semi- autonomous agency into a constitutional commission. TSC as a constitutional office provide a basis for secondary school principals and science teachers in instructional management. This puts secondary school leadership to play a key role in the delivery of quality science instruction through adequate budgetary allocation for teaching and learning resources. In practice secondary principals have the responsibility of ensuring that there is adequate budgetary allocation to support effective learning in science subjects through appropriate utilization of instructional resources. To ensure this takes place secondary schools need strategic plans plus financial management policy to guide budgeting and utilization of science instructional resources (Oyier \& Odundo, 2017). Although the importance of the instructional leadership is a responsibility of the principal, budgeting for science teaching and learning resources should be a collaborative effort. In reality, good instructional leadership skills are seldom practiced as noted by Mbugua and Rarieya (2014) secondary school principals need to be guided on a collaborative approach in budgeting for science teaching and learning resources to ensure appropriate utilization. Achieving this requires secondary schools leaderships to develop a financial management policy to guide budgetary allocation for science instructional resources (Oyier et al 2017). This is gap that needs to be addressed in order to ensure that allocation for instructional resources is adequate for quality science instructions to take place in secondary schools.

\section{Public Finance Management Act 2012;}

Articles 201(a), (d), and (e), 226, and 227 of the constitution have provisions on Public Finance relating to transparency, accountability, and appropriate governance of public monies. Public 
Finance Management Act 2012 (PEMA) operationalizes the requirements of article 201 of Constitution of Kenya (2010) and Education Act 2012 in ensuring that budgetary allocations for science instructional resources are prudently managed. It is intended to directly influence budgeting process in secondary schools and ensuring that instructional resources for science are adequately made available for quality instructions. In practice secondary schools need a financial management policy hinged on PEMA 2012 to guide budgeting for science instructional resources in a transparent and accountable manner (Oyier \& Odundo, 2017). Adoption of provisions of PEMA 2012 into secondary school financial management systems should enhance overseeing, directing, conducting, regulating and controlling in science instructional management. This will be in tandem with Mbugua and Rarieya (2014) assertion that involvement of science teachers in budgeting process for sourcing of instructional resources would go along in ensuring effecting learning in biology, chemistry and physics in Kenyan secondary schools. As PEMA 2012 operationalizes provisions in Articles 201(a, d \& e), 226, and 227 of the Constitution it provides secondary schools management with basis for effective science instructional management through budgeting process. This is possible because Article 207 of PFMA provides for participatory governance through structural mechanisms, processes and procedures. It would be necessary therefore to have school specific financial management policy incorporating tenets of PEMA 2012 to enhance accountability in budgetary allocation and utilization of science instructional resources.

\section{Science, Technology and Innovation (ST\&I) Policy of 2012}

The mandate of the education sector is to respond to the Constitution (2010) and Kenya Vision 2030 in making Kenya economic inclusive, relevant and competitive internationally. Science education in particular is an instrument for development. As noted by Oyier and Odundo (2017) science education brings global relevance and competitiveness through technological advancement and accelerating industrialization. Further, Amunga, Amadalo and Musera (2011) in an article on implications of Vision 2030 on learning achievements underscored the role of science instruction in enhancing national development through innovative technology. This could be achieved through proper implementation of Science, Technology and Innovation (ST\&I) policy 2012 as a path towards industrialization. ST\&I policy aims at creating endogenous capacities appropriate to national needs, priorities and resources which are necessary towards realization of Kenya Vision 2030. Transforming the country into a newly industrialized and middle-income nation requires a comprehensive policy framework to promote science education through quality instructions. However, as much as ST\&I policy focuses on creating a science, technology and innovation culture it lacks emphasis on the need for adequate budgetary allocation for instructional resources to make this a reality.

\section{Public Procurement and Disposal Act 2015}

Procurement of instructional resources in secondary schools in Kenya starts with setting tendering committees as required by Public Procurement and Asset Disposal Act 2015 (PPADA). The main provision of PPADA is decentralization which grants teachers and subordinate staff the power to control procurement process through tendering committees in secondary schools. Expanding membership of tender committees to include BOM and PTA members remains critical for checks and balances with such committees. Based on this, it is critical that procurement regulations be reviewed to allow the inclusion of BOM, PTA, opinion leaders, teachers and ministry representatives in school tender committees. This is likely to provide a strong mechanism for checks and balances needed by the committees to ensure budgetary allocations for every vote head are effectively utilized. Wagithunu et al (2014) acknowledged existence of guidelines on the vote heads and allocation of funds that schools in Kenya use in managing schools finances based on student numbers. As noted by Chetambve and Sakwa (2013) in Kenya through FSE policy the government meets fees of Kshs. 10,265 per 
student in secondary school of which Kshs: 3600 is tuition covering purchase of instructional resources like textbooks according to enrolment. At secondary school level, existence of a budgeting policy beyond the guidelines from MOEST would effectively guide utilization of budgetary allocation for instructional resources for science subjects from Kshs: 3600 allocated for tuition.

\section{CONCLUSIONS AND POLICY RECOMMENDATIONS}

Kenya government recognizes the key role played by science in wealth creation, building human capital and innovations required for the transition to knowledge driven economy. As proposed by Vision 2030 quality instructions in science subjects would raise productivity and efficiency levels across economic, social and political pillars in national development. Laying down appropriate implementation framework for key policies and legislations should focus on identification, acquisition, transfer, diffusion and application of relevant scientific knowledge in all sectors of the economy. To achieve this there is a need for specific provision in making sure secondary schools have adequate instructional resources for learning sciences. Such provision would lead into realization and fulfillment of education as a human right as envisioned in the article 43 of the Constitution of Kenya (2010). The right to education is a multiplier or empowerment right as well as an essential means to promote other rights. At national level focus should be on Article 13 of ICESCR which state in part that education shall be directed to the full development of human personality to strengthen the respect for human rights. Secondary school education should not only be made available and accessible through appropriate policy framework, but the emphasis should be on quality science instructions through adequate budgetary allocations. As noted in Article 13(2b) of ICESCR this can be achieved progressively to make Kenya move towards knowledge economy.

Despite having domesticated ICESCR in Constitution of Kenya (2010) there are no policy papers on issues of quality science instruction. This evident in Sessional Paper No14 of 2012 as a policy framework for education and training containing reforms anchored in Bill of Rights of the Constitution of Kenya (2010) has no specific provision for quality instructions in science subjects through availability and adequacy of instructional resources. Article 11(2) (b) and (c) of the Constitution of Kenya (2010) recognises the role of science and indigenous technologies in economic development and the promotion of intellectual property rights of the people of Kenya, but this is not achievable without adequate budgetary allocation and appropriate utilization of instructional resources. Lack of emphasis on quality instruction in science subject is evident in Basic Education Act of 2013; MOEST's policy on Science, Technology and Innovation; and Science and Technology Act of 2009. For school to adequately provide for science instructions a strategic plans plus financial management policy are needed to guide budgeting and utilization of instructional resources. Articles 201(a), (d), and (e), 226, and 227 of the constitution have provisions on public finance relating to transparency, accountability, and appropriate governance of public monies. This would require structured involvement of stakeholders budgeting process for sourcing of instructional resources in secondary schools as way of implementing provisions of Public Finance Management Act of 2012.

The study recommends that policy gaps in laws that make it difficult to operationalise provision of the constitution on education as human right and public finance management to ensure that there is availability and adequate instructional resources needs to be in place. Secondly, it is important to have policy on strengthen the capacities of principals at Kenya Education Management Institute (KEMI) on formulation of school financial management strategy. This will make secondary school principals appointed on the basis of teaching experience, academic and professional qualifications to have financial management capacities. 
Thirdly, schools should find means bringing all possible input from staff, parents, students and the community together to ensure adequate provision and utilization of instructional resources in science. On further research, the study recommends work of the effects on school financial policy on availability and adequacy of instructional resources.

\section{References}

Amunga J. K., Amadalo M. M; Musera G, (2011). Disparities in Chemistry and Biology Achievement in Secondary schools: Implications for Vision 2030, International Journal of Humanities and Social Science, 1(18), 226-236, ISSN 2220-8488 (print), ISSN 2221-0989 (0nline

Chetambve, H. N., \& Sakwa, M. (2013). Effects of Financial Training on Financial Performance of Schools in Kenya: A Survey of Administrators of Secondary Schools in Trans-Nzoia County. International Journal of Academic Research in Business and Social Sciences, 3 (10), 214 - 220.

Drah, S. T. 2011. Teachers' participation in decision making process in senior high and technical Schools in the Kwaebibirem district in the eastern region of Ghana. M.A.Thesis, University of Cape Coast. District, Kenya. Unpublished M.Ed Dissertation, Kenyatta University

Gichohi G W (2015). Stakeholder involvement in Schools in 21st Century for Academic Excellence. International Journal of Education and Research Vol. 3 No. 2 February 2015

Hussein, (2015). Teachers' Participation in School Decision Making In Secondary Schools of Arsi Zone. MA. Thesis. Haramaya University, Haramaya

Kaguri M, Njati I C, Thiaine K S. (2014) Financial Management Challenges Facing Implementation of Free Day Secondary Education in Imenti North District, Kenya Journal of Business and Management Volume 16, Issue 1. Ver. III (Jan. 2014), PP 55-78

Kipkoech L C \& Chesire S (2011). The Levels of Teachers' Involvement in Managerial Decision Making In Schools in Kenya. Problems of education in the 21st century 34, 2011 pp79-87

Kumbi H. J. (2015). Teachers' Participation in School Decision Making in Secondary Schools of Arsi Zone. Unpublished M.A Thesis of Haramaya University, Haramaya

Kung F, Huang and Cheng (2015) and An Examination of the Relationships among Budget Emphasis, Budget Planning Models and Performance. Emerald Article

Mascitti-Miller E (2012) Resource Allocation: Practices in Urban Elementary Schools. Fisher Digital Publications

Mbugua, F. \& Rarieya, J. (2014), Collaborative Strategic Planning: Myth or Reality?, Educational Management Administration and Leadership 42(1): 99-111.

Nolan A. (2013). Economic and Social Rights, Budgets and the Convention on the Rights of the Child. Intemational journal of Children's Rights 21 \{2013) 248- 277

Odundo, P. A., \& Oyier, C. R. (2017). Influence of Policy Framework on Budgeting For Science Instructional Resources in Kenyan Secondary Schools. Archives of Business Research, 5(4), 19-34.

Oyier C R and Odundo P A (2017): Participation of Science Teachers in Budgeting for Instructional Resources Secondary Schools in Kenya. International Journal for Research. Vol.5 (Iss.8): August, 2017]

Oyier C R, Odundo P A, Ngauriaya B \& Mwangi G, 2018): Science Teachers and Budget Planning for Instructional Resources in Secondary Schools in Nairobi, Kenya. Asian Education Studies; Vol. 2, No. 3; 2017

Republic of Kenya (2005): Public Procurement and Disposal Act 2005,

Republic of Kenya (20110): The Constitution of Kenya 2010

Republic of Kenya (2012): Public Finance Management Act 2012 Government Printer Nairobi

Republic of Kenya (2012): Public Finance Management Act 2012

Republic of Kenya (2013a): Basic Education Act 2013. Government Printer Nairobi

Republic of Kenya (2013b): Public Finance Management Reforms in Kenya 2013 - 2018 Republic of Kenya, 2013a).

UNESCO. (2015). Education for All Global Monitoring Report 2015. Paris: UNESCO Unpublished M.Ed dissertation in Educational Management, University of Ilorin 
Wadesango, N. 2012. The Influence of Teachers Participation in Decision-Making on their Occupational Morale. Waltersisulu University. East London, Republic of South Africa.

Wagithunu N M, Muthee J and Thinguri R (2014), A Critical Analysis of School Principals' Competence in Financial Management in Kenya: Accountability in Educational Planning and Management. Journal of Education and Practice, Vol.5, No.25, 2014

(TSC) Act 2012 Teachers Service Commission 